\title{
Moses Ibn Tibbon: Translator and Philosophical Exegete
}

\section{Introduction}

In his famous parable of the king in Guide of the Perplexed 3.51, Maimonides describes different groups of people in their physical proximity to the ruler. ${ }^{1}$ There are those who are completely outside the polis; those within the polis but who walk in the opposite direction of the palace; those facing the right direction but who are so distant from the palace that they do not see it at all; those who make their way to the outer wall of the palace and are searching for the entrance; those who have entered the palace grounds and are in the outer court; and finally, those who have entered the inner court and have come to be with the king. As typical of the parables that are brought in the Guide-and as opposed to prophetic and rabbinic parables that, according to Maimonides, are designed to conceal as much as to reveal-he offers an explanation of the parable, lest the identity of the various groups be lost upon the reader.

1 For a discussion of this parable and some of the studies dealing with it, see also chapter 2, 36-38. 
Let us begin our focus on those who made it to the palace walls but are looking for the gate. Maimonides labels them: "The jurists who believe in true opinions on the basis of traditional authority and study the Law concerning the practices of divine service, but do not engage in speculation concerning the fundamental principles of religion and make no inquiry whatever regarding the rectification of belief" (619). ${ }^{2}$ Those who have entered the gates are described as having, "plunged into speculation concerning the fundamental principles of religion." One reaching the inner courtyard is said to have "achieved demonstration, to the extent that that is possible, of everything that may be demonstrated; and who has ascertained in divine matters, to the extent that that is possible, everything that may be ascertained; and who has come close to certainty in those matters in which one can only come close to it."

One of the points that impresses the reader of the parable and its explanation is that these groups refer to divisions within the Jewish people. This stands in sharp contrast to those outside the city and those with their backs to the palace, groups that designate non-Jews in Maimonides' explanation of the parable. The enumeration of the Jewish groups begins with those who do not see the king's habitation but are facing in the right direction. Maimonides explicitly labels them "the multitude of the adherents of the Law, I refer to the ignoramuses who observe the commandments." The last phrase- "the ignoramuses who observe the commandments"-is in Hebrew rather than Arabic, lest there be any doubt among Maimonides' Jewish readers to which multitude he is referring. While the terminology employed by him in describing the subsequent groups is more neutral, and one may argue that it can also refer to jurists belonging to other religions, both the narrow context of the passage and its wider context support the view that Maimonides is referring to Jewish scholars. The "Law" (Arabic, din) is not any law, but specifically Jewish law. Only when Maimonides reaches the last group-those who know everything that can be known about divine matters in the manner most appropriate to knowing

2 All English citations from this treatise in this chapter are from Shlomo Pines's translation (Chicago: Chicago University Press, 1963). All other translations in this chapter are my own unless noted otherwise. 
them-does one begin to wonder what is specifically Jewish in his description. True, this group appears to consist of those Jews who belonged to the previous one but took the additional step. Yet could not the same description be applied to Aristotle? Did he not speculate upon "divine matters" - that is, metaphysics—ascertaining all that was possible to ascertain in the most appropriate manner possible? Did he not literally write the book on the subject?

The problem only deepens in light of the continuation of the passage. Maimonides offers a second explanation regarding those who reach the king's habitation. He indicates that those engaged in the mathematical sciences-for example, arithmetic and astronomy-are outside the walls and searching for the gates. Those who study the natural sciences have entered the antechambers. Finally, those who have achieved perfection in the natural sciences and have understood the divine science are in the inner court. In this case there appears to be no specific Jewish content to the required curriculum to reach the ruler. The curriculum is the standard philosophical one. What then is the relation between Maimonides' two explanations? Is the second one an alternative, non-specifically Jewish, way to reach perfection, which he describes in a figurative manner in terms of physical proximity to the king? Or is it complementary to the first path Maimonides lays down, both being necessary, and ultimately merging, in reaching the final goal?

Everything I have written till now is well known to scholars of Maimonides, who have debated the meaning of the parable through the ages. At stake is the question how necessary is Judaism for reaching perfection. Within the context of Judaism, there can be no higher stakes. Maimonides may be excused for being vague, and deliberately so, by not indicating the relation between the two paths of learning he presents. In fact, the vagueness itself is significant. When all is said and done, it is unclear to which group belongs Aristotle, the great monotheist and chief of the philosophers in Maimonides' estimation. ${ }^{3}$

Let us leave aside this problem for a moment and turn to a different, though related, one. How much closer do students who

3 I have dealt with this issue above, chapter 2, 36-38. 
study Maimonides' treatises get to the king in his view? Take, for example, the avid student of the Mishneb Torah, the pioneering work in which Maimonides codified all of Jewish law. He refers to this work as his "great (al-kabir) treatise," for law is the primary means for directing society as a whole in the direction of human perfection. The person studying this composition will attain true opinions (according to Maimonides) on the basis of traditional authority and will know all the practices of the divine service. But as for speculation concerning the fundamental principles, it is difficult to maintain that Maimonides supplies in this work the requisite knowledge, except for a few salient speculative details in the opening section of the treatise, "Laws of the Principles of the Torah." In short, one who studies the Mishneb Torab in detail reaches the outer wall of the palace and is still looking for the gate, according to Maimonides' parable. One may add that he also supplies directions in the Mishneb Torah, primarily in the opening section, to finding the gate and locating the key to enter, but hardly more than that. And what may be said to be the fate of the avid student of the Guide of the Perplexed? Has not this student, by the very act of careful reading and thinking about what is read, "plunged into speculation concerning the fundamental principles of religion," as Maimonides puts it, which is the key to entering the antechamber of the king's palace? Such a student will have an understanding of divine attributes, possess proofs for the existence of God, have engaged in speculation concerning divine governance, studied from a philosophic point of view the pros and cons of accepting the notion of creation ex nibilo, and learned additional significant theoretical matters that are discussed in the Guide. Moreover, this student will also absorb, by a careful reading of this treatise, the fundamentals for a true interpretation of Scripture and rabbinic midrash. From this perspective, one may say that the Guide was written as a continuation of the Mishneb Torah. The latter book brings its readers to the gate, and the former gives them entrance to the antechambers.

It is certainly clear, however, that the Guide does not bring its readers to the inner court in Maimonides' view. Many subjects belonging 
to the divine science are not covered at all, or covered only in a summary manner. At best, the Guide provides some preliminary knowledge to gaining access to the inner habitation of the ruler. Moreover, when one looks at the second path laid down by Maimonides for reaching the ruler-the path focusing on learning the sciences in their proper order-the relevance of the Guide becomes even more highly questionable. It offers almost no guidance in the mathematical sciences, little in the natural sciences, and covers topics in the divine science in a very sketchy manner at best. The crucial point is that Maimonides expects his readers to already have learnt these matters, as he indicates in the dedicatory epistle of the Guide to his student, Joseph ben Judah of Ceuta, for whom he wrote his treatise (and for those like him). In the Guide, he at times excuses himself from not entering into certain philosophic issues, such as the nature of the human intellect, directing his readers to the philosophic corpus that they should refer to instead. ${ }^{4}$ One may argue that the Guide was written for those who were driven to the second path - and in the case of his select disciple, Maimonides himself was the one who drove him in this direction-and became perplexed because they saw a conflict between this path and the first, involving the principles of religion. The Guide is designed to show that there are no real contradictions between the two paths and that they complement each other. Moreover, it essentially indicates that those who follow the first path must also follow the second one if they are to reach perfection.

I will continue to leave aside the question of whether the opposite is also true-namely, whether one who follows the second path, the learning of the sciences, must also follow the first. There can be no doubt that Maimonides regarded Judaism as the religion most conducive to the attainment of final perfection, but whether he thought it was absolutely necessary for all individuals engaged in this quest is far from clear. The important point is that he wrote the Guide, no less than the Mishneb Torah, as a Jew, directing his fellow Jews to perfection within the context of Judaism. Jews aspiring to perfection must know

4 See, for example, Guide 1.68. 
and practice Jewish law, attain the fundamental beliefs of Judaism, and engage in speculation concerning them. This speculation necessarily entails a multi-year course in the sciences, in Maimonides' view. ${ }^{5}$ Taken together, the Mishneh Torah and The Guide of the Perplexed supply the necessary knowledge for the "Jewish" aspect of the path. For the mandatory philosophic knowledge that must be attained, Maimonides refers his students to the writings of the scientists and philosophers.

Maimonides may have seen the Mishneb Torah as an effective replacement of all previous works devoted to Jewish law, as he should be interpreted as indicating in his introduction to this work, ${ }^{6}$ but he certainly did not see the Guide as a substitute for the books of science and philosophy. Significantly, when one looks at the entire corpus of his writings, one finds little inclination on his part to make any substantial contributions to the philosophic path. His contributions to philosophy in the Guide, noteworthy as they may be in their own right, are presented in order to strengthen his readers' loyalty to the Jewish aspect of the path to perfection, as Maimonides understood it. They are not presented as independent philosophic investigations-that is, independent of an understanding of Jewish principles and teachings. Even Maimonides' non-Jewish writings-namely his medical ones-are not really concerned with knowledge that is integral to the attainment of perfection, as distinct from the philosophic writings of Aristotle and his followers. On this point, Maimonides' concerns in the Guide are to be distinguished from those of his illustrious fourteenth-century Jewish philosophic successor living in Provence, Gersonides, who wrote his famous treatise, The Wars of the Lord, to convey to his readers an understanding of Judaism precisely in those areas where he felt he also had original contributions to make in the domain of philosophy. ${ }^{7}$

5 Guide 1.34. Shen Tov Ibn Falaquera was later to describe the necessary curriculum in far more detail, together with the number of years required to complete it, in his book The Seeker.

6 Maimonides writes: "I called this composition Mishneb Torab (Repetition of the Law), for a person first reads the Written Law and afterwards reads this and knows from it the entire Oral Law, with no need for reading any other book."

7 An English translation of this treatise has been prepared by Seymour Feldman, The Wars of the Lord, 3 vols. (Philadelphia: Jewish Publication Society, 1984-1999); see Gersonides' introductory remarks in vol. 1, 87-104. 
It is instructive to view the philosophic activity of the Jews of Provence from the end of the twelfth century, at the time Maimonides completed his Guide, to the first half of the fourteenth according to these two paths. Whereas Maimonides in his philosophic treatise, written in Arabic, could refer his readers to the vast corpus of philosophic literature, all available in Arabic, few Jews in Provence knew Arabic. At the end of the twelfth century this literature was still unavailable in Hebrew translation. One could say that the situation of the Jews in Provence was the opposite of the situation of part of the Jewish intellectual elite in Arabic-speaking countries. In the case of the latter, Maimonides addressed a group steeped in Jewish tradition, whom he wanted to read his treatise after they had attained also a solid grounding in the sciences. The teachings of Judaism, as they understood them, when viewed from the perspective of the physical and metaphysical sciences they had learnt, are the reason for their perplexity. The Guide shows them the compatibility of Judaism and science and their respective roles in the quest for perfection. The Jews of Provence, on the other hand, had to first read the Guide to understand that a solid grounding in the sciences is necessary for the attainment of human perfection, which is the final goal of Judaism. Maimonides himself compiles a recommended bibliography in a letter to his translator, Samuel Ibn Tibbon: Aristotle, his ancient commentators, and from the medieval philosophers-Alfarabi, Avicenna Ibn Bajja, and in a number of manuscripts of this letter, also Averroes, whose works were read by Maimonides only after he had written the Guide. ${ }^{8}$ It appears that Ibn Tibbon himself was not overly familiar with this literature. The audience for whom he was translating the Guide had no access to this literature at all. In short, we are dealing with a group of people who do not know that they should be perplexed

8 See Isaac Shailat (ed. and Heb. trans.), Iggerot HaRambam (Jerusalem: Ma'aliyot Press, 1988), 552-554. Shlomo Pines brings an English translation of the relevant part of the letter in the introduction to his translation of the Guide, "The Philosophic Sources of The Guide of the Perplexed," lix-lx. Doron Forte in an unpublished article discusses the different versions of this letter, the more trustworthy ones lacking any reference to Averroes, which appears to be a later addition of one of the copyists. That Maimonides read Averroes only after he wrote the Guide is attested to by one of his later letters to Joseph ben Judah; see Iggerot HaRambam, 299, 313. 
until they read the Guide; from the Guide they learn that they should be, and also learn the way out of the perplexity. From their reading they would certainly conclude that learning the sciences is necessary both in order to truly understand Judaism and to attain perfection. Yet precisely on this point the Provençal reader encounters the greatest obstacle. All the recommended reading on the subject is written in Arabic and unavailable in Hebrew.

Maimonides was certainly aware of the change in the function of his treatise from the one he originally intended, given the nature of his new audience. From the guide for one who has become perplexed in matters of religion because of one's philosophical studies, the treatise assumes the role of being also the guide for understanding what knowledge is required in order to become perplexed. Guiding these new readers to perplexity in matters of philosophy because of their desire to learn Maimonides' view of Judaism becomes an inevitable step in bringing them to perfection. Maimonides' correspondence with the communities of Provence shows that he admires their intellectual curiosity, but is also aware of their lack of scientific-philosophic knowledge. ${ }^{9}$ He nevertheless does not discourage the translation of his treatise into Hebrew and cooperates with Ibn Tibbon in his endeavors. While in the introduction to the Guide he tells his elite reader that he must grasp each word in any given chapter, "for the diction of this treatise has not been chosen at haphazard" (15), he informs his translator:

Anyone who wants to translate from one language to another and who translates a given word in each instance by a single word, and who also preserves the order of what is written-will toil greatly and will produce a doubtful and faulty translation. . . . The translator from one language to another must first understand the matter, and afterwards present it in the manner appropriate to the language

9 Maimonides' remarks in his letter to astrology addressed to the Jewish community of Montpellier, for example, suggests the picture of a community striving to attain knowledge of the sciences, but which still lacks basic knowledge in this area. See Shailat, Iggerot HaRambam, 478-490; for an English translation of the letter see Ralph Lerner, "Maimonides' Letter on Astrology," History of Religions 8 (1968): 143-158. 
into which it is being translated. This is impossible without changing the order of things, and translating one word by many words and many words by one. ${ }^{10}$

Maimonides' position acknowledges his readiness to compromise with an important aspect of the treatise in order to reach his new audience. $\mathrm{He}$ is willing to accept a situation in which the translation of the Guide reflects the translator's understanding of the meaning of a given sentence, and not necessarily what is the true intended meaning of each carefully chosen word. Even in its translated form, the reader of the Guide ascertains how important scientific-philosophic knowledge is, and that ultimately it does not conflict with Judaism but is mandated by it.

This picture enables us to understand Samuel Ibn Tibbon's activity, which sets the model for generations of Provençal scholars. ${ }^{11}$ In the wake of the translation of the Guide, Ibn Tibbon was pressured to begin translating the philosophic works that were necessary for an understanding of the Guide. He chose Aristotle's Meteorology, since, as Maimonides pointed out in 2.30 of the Guide, this work is necessary for an understanding of the Account of Creation. Ibn Tibbon, who himself was interested in understanding the creation story in light of Maimonides' approach, realized his own need to study Meteorology (subsequently he understood the need to study other Aristotelian works to accomplish this end). By agreeing to translate this work, he could both learn the material and begin to satisfy the demands of his patrons and the scholarly community of Provence in general. ${ }^{12}$

So the pattern is almost set. Let me continue to expand upon this story. Samuel Ibn Tibbon, as he delved more deeply into his philosophic studies, saw the need not only to begin supplying the missing literature to his environment, but also to defend the approach to Judaism advanced by Maimonides, to expand upon it, and even to

10 Shailat, Iggerot HaRambam, 532.

11 See in particular Aviezer Ravitzky, "Samuel Ibn Tibbon and the Esoteric Character of the Guide of the Perplexed," AJS Review 6 (1981): 87-123.

12 This translation has been edited and translated into English by Resianne Fontaine, Otot Ha-Shamayim (Leiden: Brill, 1995). For the reasons for Ibn Tibbon's translation of this work, see her remarks in the introduction to her translation, xi-xii. 
radicalize it. Ibn Tibbon grew up in Judaism. As in the case of Maimonides, and as a result of Maimonides' influence, he saw in philosophy the key to understanding Judaism and, so it would appear, the most important component of the path to perfection. Nevertheless, he did not view philosophy as a substitute for Judaism. Yet if one essentially accepts Aristotle's view of the structure of the world, as Ibn Tibbon did, Maimonides' position can be seen as too ambiguous, his philosophic understanding of fundamental Jewish issues too sketchy. One can say that Maimonides operates with a scalpel in guiding his readers to an understanding of the importance of studying philosophy, when the situation calls for a sledgehammer in Ibn Tibbon's evaluation. There is a fight ensuing for hearts and minds among the intellectual elite of Provence. The philosophic program must be presented with a clarion call rather than in whispers. ${ }^{13}$

One has only to consider Samuel Ibn Tibbon's most famous work, Ma'amar Yiqqavu ha-Mayyim. Even less than the Guide can it be considered a philosophic work in a formal sense. It is thoroughly a Jewish work, concerned with the exegesis of certain sections of Scripture. At the forefront of the work is the Account of the Chariot as presented in Isaiah and Ezekiel and the Account of Creation as presented by King David in Psalms (Psalms 104). This treatise in part results from Maimonides' referral to philosophic literature to understand these accounts. Ibn Tibbon is not only more explicit than Maimonides in his acceptance of Aristotelian philosophy (with strong Avicennian influences) to understand both the story of creation and the nature of the heavenly world, but is also far more expansive. He justifies his explicitness by the notion that the Gentiles possess and openly present the same wisdom that lies at the heart of the esoteric science of Judaism. Only Jews appear to now lack this wisdom as a result of esotericism. The time has come to teach these matters openly also to Jews. ${ }^{14}$ The fact that Christian circles in Provence taught Aristotelian philosophy quite

13 Significantly, the same change of attitude was taking place in the Kabbalistic circles of Provence in this period.

14 See Samuel Ibn Tibbon, Ma'amar Yiqqavu ha-Mayyim, ed. Mordechai Bisliches (Pressburg: Anton Edlen v. Schmid, 1837), chap. 22, 173. 
openly provides Ibn Tibbon with a model for emulation and a prod for his educational program. ${ }^{15}$

At one point Samuel Ibn Tibbon appears to break with Maimonides by arguing that the Torah was designed primarily for the masses. ${ }^{16}$ The difference between their positions, however, can be seen more as one of emphasis than substance. Ibn Tibbon adopts this position to show why the Torah must speak figuratively, when it would have been more appropriate to speak to the wise explicitly, much as Aristotle had done. Yet Ibn Tibbon, just as Maimonides, sees philosophic truths as underlying the Torah's accounts, as well as those of the Bible in general. He does not see himself as reading these truths into the Torah, but as unpacking them from the Torah. The Torah is true. One should add that another figure that provided Ibn Tibbon, and Provençal thinkers in general, with an important model for their approach to Scripture is Abraham Ibn Ezra, who combined an emphasis on the true literal meaning of the biblical text based on meticulous philological study with an understanding of the underlying philosophic and scientific notions. ${ }^{17}$

Samuel Ibn Tibbon also expands upon a task that Maimonides only started to engage in-understanding rabbinic midrash along philosophic terms. Maimonides wished to write a book devoted to this subject (Book of Correspondence) as he indicates both in his Commentary on the Mishnah and in the Guide. ${ }^{18} \mathrm{He}$ ultimately decided to refrain from writing it. In light of his initial intention, it is interesting to note that Maimonides brings relatively few examples of this type of exegesis in the Guide, though they certainly are far from absent. ${ }^{19}$ Provençal biblical commentators, starting with Ibn Tibbon, tend to bring far

15 For more on this point, see chapter 7, 246-247.

16 Ma'amar Yiqqavu ha-Mayyim, chap. 20, 132.

17 Samuel Ibn Tibbon, however, is fairly critical of Ibn Ezra as a philosopher. Subsequent generations of Provençal scholars, starting with Moses Ibn Tibbon, became increasingly more positive in their attitude to this dimension of Ibn Ezra's commentaries.

18 See Guide of the Perplexed, 1. Introduction, 9.

19 One has only to look at the index of rabbinic passages found at the end of Pines's translation, 655-656, to see that Maimonides continued to view the great Sages of the Talmud, such as Rabbi Akiva and Rabbi Eliezer, as philosopher-jurists. Yet it 
more rabbinic material in their elaboration upon the philosophic truths found in Scripture. Following Maimonides' view, Ibn Tibbon frequently illustrates how midrashic views are really philosophic-scientific elaborations in figurative form of Scriptural accounts, which themselves figuratively express philosophic notions. Differences of opinions among the Sages in aggadic matters reflect scientific controversies, or they may reflect different perspectives for viewing the same issue. While we may say that Maimonides provides the blueprint for this type of exegesis, the Provençal commentators, starting with Ibn Tibbon, begin to build the working models.

Ma'amar Yiqqavu ha-Mayyim is not the only work written by Samuel Ibn Tibbon in accordance with this model. His earlier Commentary on Ecclesiastes provides us with yet another example. ${ }^{20}$ The object of the model is to show the essential compatibility between, if not identification of, the philosophic path and the Jewish one. Its object is not only to make philosophy acceptable from a Jewish perspective, but also to show the truth of Judaism from a philosophic perspective. In short, the model is the product of a committed Jew who becomes committed to the philosophic pursuit but continues to maintain the commitment to Judaism. As already indicated, this exegetical model continued to be developed by the subsequent Jewish philosophic commentators in Provence, including members of his own family, such as Jacob Anatoli, author of the earliest book of philosophical sermons, Malmad ba-Talmidim. ${ }^{21}$

was more important for him in the Guide to underscore the underlying philosophic dimension of the books of prophecy.

20 This commentary was edited by James T. Robinson, who also translated much of it into English in his doctoral dissertation, "Samuel Ibn Tibbon's Commentary on Ecclesiastes" (PhD thesis, Harvard University, Cambridge, MA, 2002). The English translation of the commentary was subsequently published by him as Samuel Ibn Tibbon's Commentary on Ecclesiastes: The Book of the Soul of Man (Tubingen: Mohr Siebeck, 2007). In several passages of Ma'amar Yiqqavu ha-Mayyim, Ibn Tibbon mentions another work that he wrote dealing with the secrets of the Torah, Ner ha-Hofes. This work has not survived, not even in fragmentary form, and some scholars question whether he in fact completed the treatise.

21 Jacob Anatoli, Malmad ha-Talmidim, ed. L. Silberman (Lyck: Mekize Nirdamim, 1866). For a study of this thinker see Martin L. Gordon, "The Philosophical Rationalism of Jacob Anatoli” (PhD thesis, Yeshiva University, New York, 1974). 
The two paths laid down by Maimonides to the ruler's habitation thus give rise to two literary directions in the philosophic literature of Provence. The philosophic direction lies in the translations of the Arabic philosophic and scientific literature, philosophic compendiums such as Ruah Hen ${ }^{22}$ and eventually larger compendiums or small encyclopedias such as Sha'ar Ha-Shammayim, ${ }^{23}$ and larger encyclopedias of science such as Shem Tov Ibn Falaquera's De'ot ha-Filosofim. ${ }^{24}$ It also later gives rise to the Hebrew commentaries on the philosophic literature increasingly available in Hebrew translation, particularly the commentaries of Averroes, as well as to independent philosophic treatises. ${ }^{25}$ Many Jewish scholars not only wished to serve as middlemen but also took upon themselves the role of being actively engaged in contributing to the realms of science and philosophy. The other direction is the Jewish one, particularly philosophic commentaries on biblical literature. It is instructive to keep in mind that a good number of philosophers in Provence, from Samuel Ibn Tibbon to Gersonides, contributed to both paths-generally, however, in different compositions. Most of the compositions certainly contain both Jewish and philosophical material, but the focus is generally on one area or the other. ${ }^{26}$ With this in mind I would like to turn to the crucial, yet underappreciated activity of Samuel's son, Moses Ibn Tibbon.

22 For a study of this compendium and a critical edition of it see Ofer Elior, "Ruab Hen as a Looking Glass: The Study of Science in Different Jewish Cultures as Reflected in a Medieval Introduction to Aristotelian Science and in its Later History" (PhD thesis, Ben-Gurion University of the Negev, 2010) (Heb.).

23 For a study of this popular encyclopedia see James T. Robinson, "Gershom ben Solomon of Arles' Sha'ar ha-Shamayim: Its Sources and Use of Sources," in The Medieval Hebrew Encyclopedias of Science and Philosophy, ed. Steven Harvey (Dordrecht: Kluwer, 2000), 248-274.

24 On this encyclopedia, which has survived in manuscript but has as yet to be published, see Steven Harvey, "Shem Tov Ibn Falaquera's De'ot ha-Filosofim: Its Sources and Use of Sources," in op. cit., 211-247.

25 For a good overview of the dissemination of scientific literature among the Jews of Provence in this period, see Gad Freudenthal, "Les sciences dans les communautes juives mediévales de Provence: Leur appropriation, leur rôle," Revue des études juives 152 (1993): 29-136.

26 Gersonides' The Wars of the Lord is a notable exception to this rule in that its focus is on both areas simultaneously. It does not attempt to offer an exhaustive summary of science and philosophy or deal with all major issues involving Jewish belief. 


\section{Moses Ibn Tibbon: His Life and Works}

Among the Jewish philosophers of the Middle Ages, probably no one labored more than Moses Ibn Tibbon to make the philosophical and scientific literature written in Arabic accessible to the Jews of Christian Europe, whose cultural language was Hebrew. He belonged to the most famous family of translators in Jewish history. Yet while his grandfather Judah Ibn Tibbon and his father Samuel translated a relatively small amount of exceptionally important treatises that served as the foundation for all subsequent Jewish philosophy, most of them written in Judeo-Arabic, ${ }^{27}$ Moses translated a veritable library of the great books of philosophy and science.

Little is known of the life of Moses Ibn Tibbon. He was born between the years 1190 and 1195, probably in Southern France. During this period his father wandered around a lot, living in Lunel, the city of his birth, Arles, Toledo, Barcelona, Alexandria, and from 1211 onwards, Marseille. It appears that in Marseille, Moses lived most of his life, and from there he moved to Montpellier in 1254, or slightly earlier. From the available evidence we can deduce that he began to engage in translation in 1244. The last dated translations we have are from 1274. His extensive translations of medical literature support the hypothesis that he, like his grandfather and father before him, was a physician by occupation.

Rather, it deals with those fundamental issues that are subject to dispute from a philosophic perspective, can be understood in different ways from a Jewish one, and which Gersonides felt he could resolve in a philosophically and religiously satisfactory manner. Another notable exception, though of a different nature, is Levi ben Avraham's Livyat Hen, which will be discussed in the next chapter.

27 For a list of translations by Judah and Samuel Ibn Tibbon, see James T. Robinson and Uri Melammed, "Tibbon, Ibn," in Encyclopaedia Judaica, $2^{\text {nd }}$ edition, ed. Michael Berenbaum and Fred Skolnik (Detroit: Macmillan Reference USA, 2007), vol. 19, 712-714. For Samuel's translations, see also James T. Robinson, "Samuel Ibn Tibbon," Stanford Encyclopedia of Philosophy, http://plato.stanford.edu/ entries/tibbon/\#Tra (revised entry Feb. 10, 2010). In addition to Aristotle's Meteorology, Samuel translated a number of other scientific and philosophic treatises, or selections from them, from Arabic. 
Around 1246 Moses arrived in Naples, where he continued to engage in translation. During this period, his two sisters lived there. One of them was married to her (and Moses') uncle (their mother's brother), Jacob Anatoli, who worked in Naples as a physician in the service of the emperor Frederick II, as well as a translator of astronomic and logical literature from Arabic into Hebrew. It is conceivable that Moses traveled to Naples not solely for the purpose of visiting his family but also in search of employment. In the same year, an edict was issued in Southern France forbidding Jewish doctors to administer to Christians. If we accept the hypothesis that Moses was a physician, it is clear that he lost an important source of income as a result of this edict. Nonetheless, he did not remain in Naples for long and he returned to Marseille, where he continued his work as a translator, and later moved to Montpellier. Moses had two sons, Samuel and Judah. ${ }^{28}$

As for Moses Ibn Tibbon's activity as translator, ${ }^{29}$ he continued his father's project of making Maimonides' Arabic writings available in Hebrew by translating the Book of Commandments, the Treatise on Logic (1254), and at least a portion of the Commentary on the Mishnab. ${ }^{30}$ Some of Maimonides' medical compositions were also translated by

28 While in Naples, Moses contracted with Bella, his other sister, an agreement of betrothal between their children-Moses' son Samuel and her daughter Biongoda. Both of them eventually married others, though Samuel later on decided to sue for breach of contract. On this strange case, see Teshuvot Hokbmai Proventziyah, ed. Abraham Schreiber (Jerusalem, 1967), 54-85; and Alfred Freimann, The Arrangement of Betrothal and Marriage after the Completion of the Talmud (Jerusalem: Mossad Ha-Rav Kook, 1945), 53-56 (Heb.); and most recently, Pinchas Roth, "Legal Strategy and Legal Culture in Medieval Jewish Courts of Southern France," AJS Review 38 (2014): 382-389.

29 For a discussion of Moses Ibn Tibbon's translations, see Ernest Renan, Les rabbins français du commencement du quatorzième siècle (Paris: Imprimerie nationale, 1877), 593-595; Mauro Zonta, La filosofia antica nel Medioevo ebraico: La traduzioni ebraiche medievali dei testi filosofici antichi (Brescia: Paideia, 1996), 182-188; Ottfried Fraisse, Moses Ibn Tibbons Kommentar zum Hohelied und sein Poetologisch-Philosophisches Programm-Synoptische Edition (Berlin: Walter de Gruyter, 2004), 40-43; See also Freudenthal, "Les sciences dans les communautes juives mediévales de Provence," 60-63.

30 Only the translation of the commentary to Mishnah Pe'ah 1.1 has survived, so it is not possible to determine how much of the commentary was translated by him. 
him, such as Regimen on Health (1244), Commentary on Hippocrates' Aphorisms (1260), On Poisons and the Protection against Lethal Drugs, and On Hemorrhoids. In the area of philosophy, he translated many of Averroes' commentaries to the books of Aristotle: Epitome of On the Soul (1244), Epitome of On the Heavens and the World, Epitome of the Meteorology, Epitome of On Generation and Corruption (1250), Epitome of Parva Naturalia (1254, Montpellier), Epitome of the Physics, Epitome of the Metaphysics (1258), and Middle Commentary of On the Soul (1261). Moses did not limit himself to a translation of Averroes' works but also translated other philosophers, thereby granting them an important place in the shaping of medieval Jewish philosophy in the following generations. These treatises include Themestius' Commentary on Book Lambda of Aristotle's Metaphysics (1258), Questions on Natural Science, attributed to Aristotle (1264), Alfarabi's Book of Principles, more commonly known as The Political Regime (1273), Al-Batalyawsi's The Book of Circles, and Al-Tabrizi's commentary on the twenty propositions of Aristotelian physics that Maimonides brings in his opening to the second section of the Guide. In the field of logic, Moses translated Alfarabi's Short Treatise on Aristotle's De Interpretatione (1255), and Alfarabi's Commentary on the Isagoge by Porphyry. Basic treatises on the mathematical sciences (arithmetic, geometry and astronomy), to which Maimonides ascribed an indispensable role in preparing the student for the study of the natural and metaphysical sciences, ${ }^{31}$ were also translated by Moses, among them: Euclid's Elements with the commentaries of Alfarabi and Ibn Al-Haytham (1270), Theodosius' The Sphere, Al-Hassār's Book of Demonstration and Memorization (1271), Isagoge (or Introduction to the Phenomena) by Geminus (1246), On the Principles of Astronomy by Al-Bițrūji (1259), and Jābir Ibn Aflāh Al-'Ishbilī's Book on Astronomy (1274). Finally, Moses translated a number of important medical treatises: Al-Rāzī’s Antidotarium (1257), Ibn Al-Jazzār's Provisions for the Traveller and the Nourishment for the Sedentary (1259), Avicenna's Poem on Medicine with the commentary of

31 See Guide 1.34; 3.51. 
Averroes (1260), and Small Compendium of the Canon, ascribed to Avicenna (1272). ${ }^{32}$

While the treatises translated by Moses Ibn Tibbon played a crucial role in the subsequent development of Jewish philosophythe vast majority of them survived in numerous manuscripts and many of them were eventually published-history has not been as kind to him in regard to his independent treatises. Most of them have not survived, except for a few fragments or citations. ${ }^{33}$ The Provençal scholar Isaac de Lattes, writing in the mid-fourteenth century about the rabbis of Southern France, lists three major treatises written by Moses: "The complete sage, R. Moses Ibn Tibbon, composed great and worthy treatises, among them Sefer Leqet Shikhehot, Sefer Pe'ah, Sefer Taninim, and he also interpreted the Written Torah in an exceptionally wonderful manner." ${ }^{34} \mathrm{He}$ then proceeds to mention Moses' activity as a translator.

Let us begin with the three compositions de Lattes singles out by name: ${ }^{35}$

1) Sefer Leqet Shikbebot. This book has not survived. Moses refers to it in his Sefer Pe'ah, and Nissim of Marseille mentions it in Ma'aseh Nissim. ${ }^{36}$ From both references it is clear that this book deals with providence and good and evil, and much of its discussion is devoted to an interpretation of the relevant biblical texts. Moses refers specifically

32 For Moses Ibn Tibbon's translations of medical writings and his terminology, see Gerrit Bos, Novel Medical and General Hebrew Terminology from the $13^{\text {th }}$ Century (Oxford: Oxford University Press, 2011), 47-72. Bos, it should be noted, has produced critical editions of many of these translations, together with the original Arabic and a parallel English translation.

33 See Colette Sirat, "La pensée philosophique de Moïse Ibn Tibbon," Revue des études juives 138 (1979): 505-515. See also Fraisse, Moses Ibn Tibbons Kommentar zum Hohelied. Fraisse reedited Moses Ibn Tibbon's Commentary on Song of Songs and translated it into German. In the appendix to this edition he brings transcriptions of many of the surviving fragments from Moses Ibn Tibbon's works.

34 See Isaac de Lattes, Sha'arei Ziyon, in Seder ha-Kabbalab le-Rabeinu Menabem HaMeiri, ed. Shlomo Z. Havlin (Jerusalem-Cleveland: Makhon Ofeq, 1995), 175.

35 For a fuller discussion of these compositions, see my introduction to The Writings of R. Moshe Ibn Tibbon, ed. Howard Kreisel, Colette Sirat, Avraham Israel (BeerSheva: Ben-Gurion University of the Negev Press, 2010), 12-35 (Heb.).

36 For the references, see ibid., 15-16. 
to the first treatise in this composition, suggesting that in the other treatises this work may have dealt with other subjects as well.

2) Sefer Pe'ah. This composition has survived, at least in part, in a single manuscript (along with a number of additional fragments and citations). ${ }^{37}$ It deals with the tales and homilies of the Sages, particularly those that appear to be exceptionally far-fetched in the eyes of the intellectuals. It also brings interpretations of various biblical passages and deals with a number of scientific matters, concluding with an interpretation of the verses appearing toward the end of Ecclesiastes. In several passages, Moses refers to other compositions he wrote: The Gate of the King; The Gate of the Depiction of Existence; The Gate of Sacrifices; The Gate of the Tabernacle. The term "gate" normally indicates a section of a larger composition, thereby raising the question of whether what we know as Sefer Pe'ab is really only a section of a much larger composition containing these various gates. It should be noted that this work is labeled Sefer Pe'ab by the copyist; the name does not appear in the composition itself. ${ }^{38}$ In a single manuscript page that preserves the beginning of the composition, a different copyist writes: "The Rational Interpretation of Some of the Haggadot from the Talmud by R. Moses ben Samuel ben Tibbon." Moreover, the author of Ma'ayan ha-Ganim cites a number of passages from this treatise, referring to it as the Interpretation of Homilies (Perush ha-Derashot). Moses himself refers to The Gate of the Haggadab in his Commentary on Song of Songs. ${ }^{39}$

37 It has been published in The Writings of R. Moshe Ibn Tibbon, 81-222. For a fuller discussion of this composition see my introduction there, 39-79. See also the discussion of Colette Sirat, "Les deraisons des aggadot du Talmud et leur explication rationelle: Le Sefer Péa et la rhétorique d'Aristote," Bulletin de philosophie médiévale 47 (2005): 69-86. Sirat also brings a French translation of Moses Ibn Tibbon's introduction. Some of the salient ideas in this composition will be discussed below.

38 See MS Oxford 939, 10r. The table of contents seems to have been compiled by the copyist from the composition itself, and there is good reason to believe that some material from the original composition is missing.

39 For the various references see my general introduction to The Writings of $R$. Moshe Ibn Tibbon, 13-14. 
The matter he mentions there, however, has no parallel in our composition, so it is uncertain whether his reference is to the same work..$^{40}$

3) Sefer Taninim. This short work has also survived in a single manuscript, whose first page is missing. ${ }^{41}$ It deals with the verses and homilies referring to the giant taninim that were brought into existence on the fifth day of creation, and which Moses Ibn Tibbon identifies with the leviathans. Most of the composition focuses on geographical matters, including the location of the place where Adam was created, the location of the Garden of Eden, and the places inhabited by Adam and his descendants after the expulsion from Eden. In this composition too Moses mentions The Gate of the Tabernacle, and also appears to refer to a passage in Sefer Pe'ah.

In addition to the three compositions mentioned by de Lattes, we know that Ibn Tibbon also wrote the following works:

4) Commentary on Song of Songs. This commentary has survived in a good number of manuscripts. ${ }^{42}$ Moses Ibn Tibbon treats this book as a philosophical allegory describing the conjunction of the human material (passive) intellect with the Active Intellect by mediation of the acquired intellect. He divides Song of Songs into three major sections: 1) $1: 1-2: 17$, a description of the material intellect; 2) 3:1-5:1, a description of the individual of perfect intellect who achieves conjunction with the Active Intellect and immortality (one who eats from the Tree of Life); 3) 5:2-end, a description of one who succumbs to one's physical inclinations (one who eats from the Tree of Knowledge of Good and Evil) and who will not experience eternal life. In this commentary, Moses refers to the following compositions that he wrote: The Gate of Seven Weeks, The Gate of the Garden, The Gate of the Counting of the Omer, The Gate of the Haggadah.

40 Yet, as has been pointed out above, there appears to be material missing from our composition.

41 It too has been published in The Writings of R. Moshe Ibn Tibbon, 233-258. For a discussion of the ideas in this composition, see my Hebrew introduction there, 225-232.

42 The commentary has been published twice, once by L. Silberman (Lyck: Mekize Nirdamim, 1874), and once by Ottfried Fraisse (see above, note 29). 
Overall, in his surviving compositions Moses refers to Leqet and to eight gates: 1) The Gate of the King; 2) The Gate of the Depiction of Existence; 3) The Gate of Sacrifices; 4) The Gate of the Tabernacle; 5) The Gate of Seven Weeks; 6) The Gate of the Garden; 7) The Gate of the Counting of the Omer; 8) The Gate of the Haggadah. ${ }^{43}$ Leqet clearly has the status of an independent treatise, but what is the status of the other compositions? Are all these "gates" parts of a larger work, as it highly unusual to refer to an independent work as a "gate," and if they are parts of a larger work, what was its name? One possibility is that Sefer $P e^{\prime} a b$ is the name of the all-inclusive work to which all these "gates" belong, including the composition on the rabbinic homilies mentioned above (The Gate of the Haggadah?), as well as the Commentary on Song of Songs, which are the only "gates" that have survived. This possibility also explains why Moses did not mention the name of the composition in the introduction to the composition we know as Sefer Pe'ah, which is unusual; the introduction was only intended for this particular "gate." Yet several objections may be raised against this hypothesis. References to The Gate of the Tabernacle appears in both Sefer Pe'ab and Sefer Taninim. De Lattes refers to them as independent compositions, and if this is the case, they cannot contain the same "gate." Furthermore, the Commentary on Song of Songs contains an extensive introduction, was copied numerous times as an independent composition, and does not appear to be a section of a larger work, though it contains references to many of the "gates" Moses Ibn Tibbon wrote. Could these various "gates" have been written originally as independent compositions that Moses subsequently decided to combine? Or perhaps he preferred to name many of his independent compositions "The Gate of ...." Another possibility is that the copyists simply chose to copy the section of the larger work that interested them, and Moses indeed wrote a multi-faceted work containing different topics pertaining to Judaism. A further question concerns de Lattes' description of Moses Ibn Tibbon's compositions. He does not mention the Commentary on Song of Songs or any of the "gates," but speaks of Moses' interpretation of the Written

43 For the content of these "gates," see The Writings of R. Moshe Ibn Tibbon, 17-20 
Torah. Was he referring to these various gates collectively, or was he thinking of a different composition? We shall return to these questions shortly after examining some of Moses' other compositions.

In addition to the above mentioned treatises, two others have survived that many of the copyists attribute to Moses Ibn Tibbon:

5) Perush ha-Azharot le-Rav Shelomo Ibn Gabirol. ${ }^{44}$ Moses is not identified as the author in the body of the commentary, nor does the commentary contain any reference to his other compositions. Two of the copyists, however, ascribe this work to him, as does the great late fourteenth-early fifteenthcentury Spanish rabbi, Shim'on ben Zemah Duran. This composition is not solely an attempt to identify all the 613 commandments that Ibn Gabirol presents in poetic form, but also, and perhaps primarily, to present a detailed comparison between Ibn Gabirol's list of commandments and that of Maimonides. This commentary thus appears to have been written after Ibn Tibbon's translation of Maimonides' Book of Commandments, and its main purpose was to promulgate Maimonides' list of the commandments among Provençal Jewry by incorporating it into a commentary on the most famous of the azharota poem presenting all the commandments. In this commentary, Moses displays an impressive mastery of Jewish legal literature, in addition to knowledge of Hebrew philology.

6) Sefer 'Olam Qatan (The Book of the Microcosm). ${ }^{45}$ Many manuscripts of this composition have survived and most of the colophons identify its author as Moses Ibn Tibbon. ${ }^{46}$ As opposed to the more famous treatise of Joseph Ibn Zaddik by the same name, Ibn Moses' treatise reflects more of an Aristotelian influence than a Neoplatonic

44 This commentary has been published in The Writings of R. Moshe Ibn Tibbon, 279-421. For a discussion of this composition, see Avraham Israel's introduction, 261-277.

45 The book was edited by Zvi Almog, "Critical edition of Moses Ibn Tibbon's 'Olam Katan" (PhD thesis, Dropsie College, Philadelphia, 1966), who in his introduction traces the idea of the human being as a microcosm of the world in medieval Jewish thought.

46 Ibid., 89, 119. It should be added that Levi ben Avraham cites an interpretation in the name of Moses Ibn Tibbon that has a parallel in this composition, lending further support to the view that it was indeed written by this author. See The Writings of R. Moshe Ibn Tibbon, 21. See below, chapter 5, 132. 
one, though the influence of the latter is also present. ${ }^{47}$ The treatise deals with the three main faculties of the soul-the spiritual (rational), the vital, and the natural-divides each of them into several functions, and ascribes each of them to a different major organ in the body: the brain, the heart, and the liver. Moses points out the similarity of each of these faculties to one of the three "worlds," or levels of existent things: the Separate Intellects, the Spheres, and the world of generation and corruption, and how each organ is similar to a different part of the world of the Spheres. He also shows how the various motions of human beings also share some similarity with the motions of the spheres. ${ }^{48}$ While the treatise focuses almost exclusively on philosophic matters, Ibn Tibbon shows how some of these matters underlie one of the strange rabbinic homilies regarding the fallen angels Shamhazai and Azazel. ${ }^{49}$

He wrote two other treatises that have not survived:

7) Sipur Toldot ba-Avot ve-Zulatam min ha-Qadmonim (The Account of the Descendants of the Patriarchs and Others from among the Ancients). Moses Ibn Tibbon mentions this book toward the beginning of his Sefer 'Olam Qatan: "After having written in The Account of the Descendants of the Patriarchs and Others from among the Ancients what appears to me, in which I alluded to the matter of the soul and what part of it may possibly survive and attain immortality ... and I elaborated upon the account of their descendants and their many divisions, in order to reinforce this matter and confirm it in order that it be known, for many reject it-it

47 For example, Moses speaks in the treatise of the Universal Soul-a notion that he may have borrowed from Al-Batalyawsi's The Book of Circles-that serves as an intermediary between the active supernal entities and the passive entities composed of the four elements, enabling each of them to receive its essence, shape, limbs, and unique appearance. See 'Olam Katan, 116-117.

48 For a study of another central idea of this composition, see Ottfried Fraisse, "Moses Ibn Tibbon's Concept of Vital Heat: A Reassessment of Peripatetic Epistemology in Terms of Natural Science," in Jewish Philosophy: Perspectives and Retrospectives, ed. Raphael Jospe and Dov Schwartz (Boston: Academic Studies Press, 2012), 255-278.

49 See The Writings of R. Moshe Ibn Tibbon, 21. 
being strange in their eyes and close to impossible." 50 A further apparent allusion to this treatise can also be found in the Commentary on Song of Songs, where he writes: "The faculties of the soul are four: the sensitive, the imaginative, the appetitive, and the rational, and these are generally the 'Chariot of Pharaoh,' for it [the evil inclination] overpowers and rules them .... The nutritive faculty was not counted among [the faculties] of the human soul, because it is entirely natural and is found also in plants. It was also not listed among the number of wives of Jacob and their children, as I explained in its place." 51 The allegorical treatment of Jacob and his family, in which Jacob represents the intellect and each of the wives and children represent a different power of the soul, is cited in detail by Levi ben Avraham in the name of Moses Ibn Tibbon. ${ }^{52}$ Though Levi does not mention the name of the composition, there is little doubt that he draws his citation from this work. In this case too, the impression one gains from Moses Ibn Tibbon's references to this work is that Sipur Toldot ha-Avot, Sefer 'Olam Qatan, and Commentary on Song of Songs are all sections of a larger work and appear in it in this order.

8) Supercommentary on Abrabam Ibn Ezra's Commentary on the Torah. This supercommentary has not survived at all. We know of it from other supercommentaries on Ibn Ezra, which cite Moses Ibn Tibbon's comments on Ibn Ezra's views. Many of these citations are not necessarily derived from a supercommentary that he wrote, but may have been taken from one of his other lost works. Yet at least one supercommentator, Yehudah Mosconi, mentions explicitly having read a supercommentary ascribed to Moses Ibn Tibbon, of which he is critical, though occasionally he cites from it in his own work. ${ }^{53}$ Whether

50 'Olam Katan, 90.

51 Commentary on Song of Songs 1:9 (Silberman, 10a; Fraisse, 229).

52 See Livyat Hen: The Secrets of the Faith and the Gate of the Haggadah, ed. Howard Kreisel (Beer-Sheva: Ben-Gurion University of the Negev Press, 2014), 146-147 (Heb.). See also Livyat Hen: The Quality of Prophecy and the Secrets of the Torah, ed. Howard Kreisel (Beer-Sheva: Ben-Gurion University of the Negev Press, 2007), 716 (Heb.).

53 See Abraham Berliner, "R. Yehudah Mosconi: The Introduction to Even ha-'Ezer on R. Abraham Ibn Ezra's Commentary on the Torah," Ozar Tov 2 (1877): 8 (Heb.). For a survey of the supercommentaries written on Ibn Ezra's Torah commentary, see in particular Uriel Simon, "Interpreting the Interpreter: Supercommentaries on 
this supercommentary was in fact written by Moses, however, is not entirely clear. ${ }^{54}$ Also unclear is whether this is the composition that de Lattes has in mind when he refers to Moses Ibn Tibbon's interpretation of the Written Torah.

Finally, there are two surviving short works that Moses Ibn Tibbon wrote:

9) Moses Ibn Tibbon's Comments on his Father's Letter to Maimonides regarding Providence. ${ }^{55}$ While Samuel sees a possible contradiction in Maimonides' approach to individual providence, with some of his comments suggesting that this is a completely naturalistic phenomenon while others suggest that it is a supernatural one, Moses sees Maimonides positing two forms of individual providence, one belonging to the philosophers and the other to the prophets, with both of them being natural..$^{56}$ These comments either were part of an epistle or were copied from a larger work, such as Leqet Shikhehot. ${ }^{57}$

10) Answers to Queries on Physics (also known as: Answers to Queries on Ma'amar Yiqqavu ha-Mayyim)..$^{58}$ This epistle has survived in a single

Ibn Ezra's Commentaries," in Rabbi Abraham Ibn Ezra: Studies in the Writings of a Twelfth-Century Jewish Polymath, ed. Isadore Twersky and Jay M. Harris (Cambridge, MA: Harvard University Press, 1993), 86-128.

54 While there is no compelling reason to reject Moses Ibn Tibbon's authorship, there are at least some reasons to question it. For a discussion of this point see The Writings of R. Moshe Ibn Tibbon, 23-25. Another early supercommentator, Solomon Ibn Yaish the Younger, also notes having seen Moses Ibn Tibbon's commentary and brings an additional citation in his name, in this case explaining Ibn Ezra's parable found in his commentary on Genesis 3:24, "From the light of the Intellect the Will is emitted ...." Overall, the available evidence supports the view that Moses wrote a supercommentary on Ibn Ezra's Torah commentary, though this issue requires further research.

55 Samuel's letter and Moses' response were published by Zevi Diesendruck, "Samuel and Moses Ibn Tibbon on Maimonides' Theory of Providence," HUCA 11 (1936): 341-366.

56 See below, chapter 11, 411-415.

57 See The Writings of R. Moshe Ibn Tibbon, 26.

58 This treatise has been analyzed in depth by Hagar Kahana-Smilansky, "Moses Ibn Tibbon's Answers to Queries on Physics: Sources and Problems," Aleph 12 (2012): 209-241. 
manuscript whose copyist attributes it to Moses Ibn Tibbon. ${ }^{59}$ It deals primarily with the motion of the four elements in light of questions asked regarding some of Samuel Ibn Tibbon's statements in Ma'amar Yiqqavu ha-Mayyim. The questioner, apparently a close relative, also asks why Samuel brings more than one interpretation of Jacob's ladder in his treatise, leading Moses to discuss this particular vision.

It should be added that a number of citations from Moses Ibn Tibbon can be found in the writings of subsequent thinkers, particularly Levi ben Avraham, without their mentioning, however, from which works they are taken. ${ }^{60}$

In light of de Lattes' remarks, we are left with the question of whether Ibn Tibbon wrote a commentary on the Torah, or was de Lattes thinking of the various "gates" as collectively comprising a commentary. Moreover, did Moses intend for these "gates" to form a single encyclopedic composition, one which could have served as a forerunner for the Jewish section of Levi's encyclopedia? ${ }^{61}$ Until more evidence regarding Moses Ibn Tibbon's treatises comes to light, the answers to these questions will have to remain in the realm of speculation.

\section{Moses Ibn Tibbon's Approach to Aggadah}

Moses Ibn Tibbon's knowledge of Arabic and his numerous translations of philosophic and scientific treatises provided him with a solid background for the development of his own thought. ${ }^{62} \mathrm{He}$ presents a

59 MS Parma 2620, 91v-99v. Kahana-Smilansky has edited the text which is scheduled to be published by Brill.

60 For some of these citations, see The Writings of $R$. Moshe Ibn Tibbon, 28-33. There are also a number of surviving fragments from other works that some have attributed to Moses Ibn Tibbon, one dealing with the beginning of Maimonides' "The Laws of the Foundations of the Torah," and several containing part of a commentary on the Work of Creation. Some of these fragments are clearly not the work of Moses Ibn Tibbon, or at least there is no solid reason to assume that they are, except for one of the fragments dealing with the Work of Creation that may in fact belong to him. For a discussion of this point, see The Writings of $R$. Moshe Ibn Tibbon, 33-34.

61 For a discussion of this encyclopedia, see the following chapter.

62 It should be noted that he at times cites from Arabic treatises that had not yet been translated. 
number of interesting general philosophic ideas in his surviving treatises, such as in his Book of the Microcosm, and his approach to individual providence as discerned from his comments upon his father's epistle to Maimonides should be regarded as a significant contribution to Jewish thought. ${ }^{63}$ Yet his primary contribution as a thinker is in the area of philosophic exegesis - the interpretation of Jewish sources in light of philosophic and scientific notions. He continues the project his father began, explaining the philosophic ideas concealed in King Solomon's works by writing an exceptional philosophic commentary on what is considered to be the most esoteric of them, Song of Songs. Moreover, he went much further than his illustrious predecessors in presenting in his works philosophic-scientific interpretations not only of rabbinic homilies (midrashim), but also tales (aggadot), particularly in his Sefer $P e^{\prime} a h$. In a crucial sense, Sefer Pe'ah (or the section we possess of it) is a pioneering work in the philosophic interpretation of this genre of literature. ${ }^{64}$

In the introduction to this composition, Moses deals explicitly with the reasons that the Sages concealed their philosophic and scientific views by presenting them in an allegorical form. It is important to note that he does not feel that all the tales have a concealed layer, or that all the Sages were also philosophers, but in many cases such a layer indeed exists in his view. As for the reasons they concealed philosophic and scientific truths in this manner, he writes as follows:

According to the thinking of the Sages, some matters should be presented in strange parables, which cannot possibly be true according to the intelligent, ${ }^{65}$ in order that the intelligent discern that they in fact are parables and that they contain a concealed layer, and hence they must exert themselves in order to discover their meaning. Moreover, if you inform the ignorant and the foolish of

63 See below, chapter 11, 420-421.

64 A Provençal contemporary of Moses Ibn Tibbon who also wrote a rationalistic commentary on the aggadah, but who was far less grounded in philosophy, is Isaac ben Yedaiah; for a study of his composition, see Marc Saperstein, Decoding the Rabbis: A Thirteenth-Century Commentary on the Aggadab (Cambridge MA: Harvard University Press, 1980).

65 That is, when they are understood literally. 
the acts of God and His wonders as they really are, or inform them by rational parables of the justness of the order and God's wondrous intelligence, they will not understand and will not believe in God's ability or the goodness of His will, but will ascribe these matters to a wise and fixed nature. Therefore the Sages, that is to say, those who were true sages, thought to depict these true matters by fantastic parables that are strange and remote from what is known by the intellect as well as from nature. The ability of God and the goodness of His will are thereby increased in the eyes of the foolish, in [their belief] that God multiplied His wonders and miracles for His loved ones and those keeping His covenant. Therefore, anyone who is intelligent and has the spirit of God in him, when he sees a strange tale or saying ascribed to the Sages he should know that this matter has a concealed layer, and its strangeness is designed to astonish the foolish and to encourage the intelligent to understand what is hinted by it. ${ }^{66}$

Moses has no doubt that the concealed layer consists of philosophic and scientific views contained in the Arabic literature. As he indicates, the main reason that these views are concealed is that they are not conducive to strengthening the masses' belief in God and divine providence-that is to say, for political-religious reasons. As Maimonides had already noted, the more absurd a midrashic view is when understood literally, the more the masses (including those rabbis ignorant of philosophy) think it as reflective of God's might. ${ }^{67}$ The wise, on the other hand, will discern that there is a concealed layer and discover its true meaning by dedicating themselves to learning the sciences and

66 The Writings of R. Moshe Ibn Tibbon, 89-90. It is interesting to read these lines in light of Gershom Scholem's view on the difference between the approach of the philosophers and the Kabbalists to aggadah. Of the philosophers Scholem writes: "Their treatment of the Aggadah . . . is embarrassed and fumbled." Subsequently he argues: "The philosophers who had passed through the school of Aristotle, never felt at home in the world of Midrash. But the more extravagant and paradoxical these Aggadahs appeared to them, the more were the Kabbalists convinced that they were one of the keys of the mystical realm" (Major Trends in Jewish Mysticism [New York: Schocken Publishing House, 1941], 31, 32). Moses Ibn Tibbon's approach is not as distant from that of the Kabbalists as Scholem would have it. Moreover, the philosophic approach to midrash may have even played a positive role in the development of the Kabbalistic approach, but this point requires further investigation.

67 See Guide 2.6. 
philosophy, thereby understanding the true manner in which God governs the world.

As in the case of his father, the cultural climate in Provence provided Moses Ibn Tibbon with a strong catalyst in bringing to light the truths that he thought the traditional texts of Judaism concealed. Yet while his father spoke of the scathing criticism voiced by the Christians in regard to the Jewish ignorance of the philosophic ideas underlying the words of the prophets, which prodded him to make some of these ideas public, ${ }^{68}$ Moses focuses on their withering critique of rabbinic midrash:

Since I saw the gentile sages scheme against us by investigating the words of our tradition, and ridicule us and our holy ancestors, the authors of the Talmud, for the tales found in it are strange to the intellect and impossible by nature, despite the fact that they for the most part contain matters intended for those understanding their secrets. This [ridicule] befell us because of those among our nation who are wise in their own eyes, and pretend to be wise though they are without wisdom, who understood them [the tales] literally, just as is the case with many of the parables of Scripture and its esoteric allusions. They do not distinguish between natural matters and those brought about by way of miracle, and they do not understand the difference between the impossible, the possible, and the necessary in regard to God, and what must be negated of Him. They do not know that the way of the sages of all the nations in antiquity was to speak of the sciences in parables and riddles and to hint by way of stories what befell them, their histories, moral matters, and the sciences, and that many of their words have an exoteric and esoteric layer. Therefore I, Moses ben Samuel ben Judah ben Tibbon from Spain [lit. the pomegranate of Spain], gathered up my strength and stirred myself to explain some of them, particularly the strangest ones, and to confirm their intent, to serve as a hint and allusion to some, and to show the way to understanding others, and to speak of some of them in a way that is possible, not that I declare that it is definitely so [in accordance with my explanation]. ${ }^{69}$

The investigation of Jewish sources by Christians, in an attempt to convince the more educated Jews to convert due to the absurdity of

68 See Ma'amar Yiqqavu ha-Mayyim, chap. 22, 175; see below, chapter 7, 246-247.

69 The Writings of R. Moshe Ibn Tibbon, 83. 
many of the Talmudic tales, plays an important role in Moses' decision to devote a composition to this subject. ${ }^{70}$ This problem is greatly aggravated, he maintains, by the tendency of many of the Jewish legal scholars in his own period to accept these stories as true in accordance with their literal meaning - a tendency that Maimonides had severely criticized in his Introduction to Pereq Heleq. When he speaks of the approach of the sages of antiquity, Moses clearly has in mind the Platonic understanding of myths. It is important to note that not only scientific matters are on occasion presented in parable form according to him, but historical events as well. ${ }^{71}$ As we shall see below, he brings some exceptionally interesting examples of such parables from rabbinic literature.

In the continuation of his discussion, Moses addresses the problem of whether one is required to believe everything that is contained in rabbinic aggadot, just as one is required to accept all the commandments that are handed down in tradition and recorded in the Talmud:

Regarding the aggadot and stories that are written in the Talmudwhether they concern natural science and astronomy, the divine science, or matters necessary to uphold the faith, as in the case of the stories regarding reward and punishment, either during one's lifetime or after one's death, or other matters-it is not written in what manner they are to be known, or how we are to establish what is true when there are conflicting opinions [between the Sages]..$^{72}$ Furthermore, when there are no conflicting opinions, are we still required to believe everything that is written on these matters, even though they are irrational and impossible by nature when understood literally?

70 Ram Ben-Shalom has suggested in an unpublished talk that Moses Ibn Tibbon's reference may be to Pablo Christiani. Christiani, who probably was born in Montpellier, was a Jewish convert to Christianity who tried to convert his former co-religionists in Provence by his preaching. Later he moved to Aragon, and in 1263 was the adversary of Nahmanides in the Barcelona Disputation. Reports of the disputation reveal that the absurdity of many of the rabbinic homilies and tales was one of the points Christiani raised to illustrate the falseness and irrationality of Judaism.

71 Maimonides had already shown that a number of biblical parables should be understood as referring to future events; see, for example, Guide 2.29.

72 According to Maimonides, in matters of opinion, as opposed to matters of action, there is no room to issue a legal ruling in cases of conflict; see, for example, Commentary on the Mishnah, Sanhedrin 10.3. 
Also, there are matters that are ascribed to "Tana devei Eliyahu," and we do not know if this is the name of the possessor of the baraithot, ${ }^{73}$ or they are so labeled because they were received from the mouth of Elijah [the prophet] in a dream and vision of the night, or they are matters that are acquired by way of learning, logical deduction or tradition, and they are so labeled in order to conceal. We do not know if we are required to believe everything. ${ }^{74}$

Based on Maimonides' discussion in Guide 2.8, where he shows that the Sages of the Talmud deferred to the opinion of the gentile sages in matters of astronomy, Ibn Tibbon concludes that we are certainly not required to believe what the Sages said in matters of science and philosophy when no commandment or matter of faith is involved, if their opinions are irrational or when other sages demonstrated their falsehood. This is true even when the rabbinic opinion appears to follow the prophetic one. The established scientific opinion remains the preferable one.

Yet the primary purpose of this composition, as we have seen, is to show the conformity of the rabbinic views with the scientific ones to the extent that Ibn Tibbon thought possible. The interpreter should, he maintains, struggle to show how these tales reflect concealed truths. He concedes, however, that not all statements and tales should be treated in this manner-that is to say, as containing an esoteric level. Many of them should be seen as employing hyperbole in the descriptions they bring. Other tales should not be ascribed to the Sages themselves, for some of those written by non-sages were incorporated into rabbinic literature. Moses divides the tales and homilies into the following categories: some are simply stories meant for entertainment; some interpret a verse in many different ways, of which only one alludes to an esoteric truth, while the others are designed to conceal; some are presented in order to strengthen the faith or to negate a false belief in the manner that is most appropriate for the readers. In other words,

73 That is to say, a Sage from the period of the Mishnah who is responsible for transmitting these teachings.

74 The Writings of R. Moshe Ibn Tibbon, 88. 
these tales are necessary for the preservation of the religion, even though they are not true. ${ }^{75}$

One of the strangest aggadic statements discussed by Moses Ibn Tibbon is the one in BT 'Avodah Zarah 3b:

The day consists of twelve hours. During the first three God sits and devotes to Torah; during the second [three] He sits and judges the entire world. Since He sees that it merits annihilation, He gets up from the Throne of Judgment and sits on the Throne of Mercy. During the third [three] He sustains the entire world, from antelope horns to lice eggs. During the fourth [three] He sits and plays with [an alternative reading, ridicules] the leviathan, as it is said: The leviathan you formed to play with [Psalms 104:26].

Given the patent absurdity of this aggadah when understood literally, Moses interprets it as a philosophic parable. In his view it deals with the four stages of life, particularly of human beings. The first stage is the period of birth and growth of the entity, likened to the first three hours of the day, which are warm and moist as in the nature of Spring, the season of renewal. God studying Torah alludes to the divine wisdom that produces birth and growth of all life forms composed of the four elements, until the entity is fully formed. The next stage, likened to the second three hours of the day, alludes to the period in which the entity functions at full physical capacity and in which the food it intakes enables it to replace the bodily matter which is expended-"judgment" representing the sustaining of that which exists in an orderly, fixed manner. By the end of this period, however, most of the natural moisture the entity possessed at birth has dried up, leading to the entropy of the body, characteristic of the next period. Hence in order to continue to sustain the entity, whether it be large or small, and enable it to function with the power of all its faculties despite the weakening of the body, God must now sit on the Throne of Mercy, for everything we see deteriorating we say that it requires heavenly mercy. In the final stage, the body is weak and diminished together with all its powers, and is like naught before God, who is represented as sitting in the heaven,

75 Ibid., 89. Ibn Tibbon also points to the different types of parables enumerated by Maimonides in the introduction to the Guide. 
the eternal existent, and ridiculing it. Leviathan alludes to the corruption of entities, or to the evil inclination, which also weakens in old age. God ridicules it and informs it that it toiled in vain in seeking out physical pleasures. In a similar vein, Ibn Tibbon interprets the subsequent Talmudic discussion regarding God and the leviathan, and God's nocturnal activity. ${ }^{76}$

Other strange tales, such as the story in BT Berakhot 18b of the righteous person who gave a dinar to a poor person, was forced out of his home by his wife as a result, and went to sleep in the cemetery, he also treated as philosophic parables-in this case, as one dealing with the intellect and the faculties of the soul. ${ }^{77}$ The strange statement in BT Sukah $4 \mathrm{~b}-5 \mathrm{a}$ that the Indwelling did not descend below ten handbreadths and Moses did not ascend above ten, is explained as having an exoteric and esoteric meaning. On the exoteric level, it indicates that Moses received his revelation in the Sanctuary between the figures of the two cherubs above the curtain of the ark, which were higher than ten handbreadths from the ground. On the esoteric level, the ten handbreadths represent the ten spheres. The statement signifies that God had no direct connection with the material world, even the world of the spheres, while the human being cannot fully grasp even the ten spheres, let alone the Separate Intellects above them, only what is below, the world of generation and corruption. ${ }^{78}$

An example of an aggadic statement that conceals a philosophic idea precisely because it is not so strange, at least not at first glance, and only the wise will discern that it contains an esoteric level, Moses Ibn Tibbon discerns in BT Pesahim 54a. The passage deals with the ten things that God created on the very end of the sixth day, all of them referring to miraculous objects that will play an important role in Israel's future. While Maimonides interprets the parallel passage in Mishnah Avot 5.6 as showing the extent that the Sages tried to understand miracles as in some manner being incorporated into the order of

76 Ibid., 95-102.

77 Ibid., 196-197.

78 Ibid., 109-110. 
nature at the time of creation, ${ }^{79}$ Moses focuses on one of the things added to this list and the subsequent debate about it, which upon reflection is incongruous to the original list:

"Ten things were created [on the eve of the Sabbath] at twilight. . . . R. Judah said: tongs too." On R. Judah's saying "tongs too," they [the Sages] stated: "He used to say: 'Tongs are made with tongs, but the first tongs, who made them? Verily it was a heavenly creation.' They said to him: 'It is possible to make a mold and shape it simultaneously, hence it is a human creation.' "It is remarkable that R. Judah was oblivious to the fact that it is possible to make tongs in a mold or with two tiles. Hence it appears to me that R. Judah alluded to a very subtle esoteric matter and connected it to the things that were created at twilight. That is, the things that by nature are necessarily generated one from another were not necessarily created in order, the second from the first and the third from the second. For it is known to the wise and agreed upon by them that the First Cause, God the highly exalted may He be blessed, is one. He is a true unity, who is simple, separate, with no multiplicity or composition at all. All the philosophers are of the opinion that from a simple thing only a simple thing is necessitated, for the agent gives what is in itself to its effect. The Separate [Intellects] are not numerous or distinct, except by rank and causality ${ }^{80}$ Tongs and scissors are composed of two things, the actual existence of one is not possible without the other. They represent the matter and form in the lower world of generation and corruption, made and existing by reason of the body of the sphere and its shape. It is possible that from the aspect of the body of the sphere, which is finite, the individuals of each species are generated; and from the aspect of its circular shape and motion, which has no beginning and end, first and last, they turn not when they go, each goes in the direction of its face [Ezekiel 1:9] — this refers to the preservation of the species by one coming after the other, $a$ generation goes and a generation comes [Ecclesiastes 1:4], whether by virtue of birth, in the case of humans and animals, by eggs, in the case of fowl and fish, or seeds, in the case of vegetation, or by parts of roots, like garlic and roses. The continuation of the species is by

79 See Commentary on the Mishnah, Avot, 5.6; cf. Guide 2.29.

80 That is to say, members of the same species are distinguished by their matter, since their form is the same. Since the Separate Intellects have the same form and no matter, the only way that one can be distinguished from the other is by rank, which is determined by the distinct level of knowledge of each of them, or by the fact that one is the cause of the other. 
means of the individuals of the species, in accordance with its period [of existence] in time and the end of its motion, rising and descending. But "the first tongs," which are the body of the sphere and its shape, "who made them"- how do they come about by reason of the Separate Intellects, and how did they derive from them and their power? This is not possible from the aspect of natural necessity. Therefore, the world is created by virtue of [divine] will, and His will has no mover and cause, unlike the will of a human being, as it is said: $M y$ thoughts are not your thoughts [Isaiah 55:8]. Heaven forbid that one should say that the sphere, which is the Throne of Glory, is without beginning, as the Sages said that the Torah and the Throne of Glory antedated the work of creation. ${ }^{81}$ Rather, the Throne and His Footstool belong to the things that are inseparably joined together, like the circle and its center. ${ }^{82}$ The reason that "the first tongs" are connected to the things that were created on the twilight of the end of the six days of creation is because they are not necessitated by natural necessity - a thing that is necessitated by what preceded it and its being the reason for it . . . ${ }^{83}$

The view of $\mathrm{R}$. Judah regarding the existence of the first tongs, according to Ibn Tibbon, in effect is an argument for the doctrine of creation. Based on Maimonides' discussion in Guide 2.22, Ibn Tibbon points out that natural necessity cannot account for the origin of the spheres-to which R. Judah alludes when he speaks of the first tongs-for according to the philosophers, only a simple thing can proceed from a simple thing. The existence of the spheres thus must be the product of divine will, even though the Separate Intellects are their immediate cause. Moreover, since the existence of the spheres and the earth are inseparable, they must have come into existence at the same time. This view is tied by $\mathrm{R}$. Judah to the list of miracles implanted in creation, Ibn Tibbon explains, since they too could not have come about as a result of natural necessity alone, but they reflect the workings of divine will.

While Moses Ibn Tibbon's philosophic interpretations of some of the rabbinic homilies and tales display a high degree of ingenuity, more

81 See BT Pesahim 54a; cf. Genesis Rabbah 1.4.

82 The Torah represents the Separate Intellects, the Throne represents the spheres, and the Footstool represents the earth. Moses Ibn Tibbon argues that the spheres and the earth are inseparably linked, so one cannot exist before the other in time, though the former is the cause of the latter.

83 The Writings of $R$. Moshe Ibn Tibbon, 93-94. 
novel are his historical interpretations. A good example of this is his fascinating explanation of the tale in BT Berakhot 54b involving the stone thrown by $\mathrm{Og}$ upon Moses:

"One who sees the stone that $\mathrm{Og}$, the king of Bashan, threw upon Moses ...." ${ }^{44}$ The object mentioned in this baraitha is possibly a large stone thrown by Og upon Moses, or many stones thrown upon the camp of Israel, "stone" representing many stones and "Moses" representing all of Israel. These are stones used as projectiles or stones thrown from belfries, thus they said "stone" and not "mountain." . . . "He $[\mathrm{Og}]$ said: How large is the camp of Israel? Three parsangs. I will go and uproot a mountain that is three parsangs and throw it upon them and kill them. He went and uprooted a mountain that was three parsangs" etc. until the end of this tale in the Talmud, up to "[don't read] 'You broke' [Psalms 3:8], but 'You stretched." The literal meaning of this story is very strange, far removed from nature and reality, and something that the intellect cannot accept, that such a thing was within the power of human beings, let alone God's enemies, even by way of a miracle. The Talmud, however, understood this story as involving a powerful king or noble, who was to help him $[\mathrm{Og}]$, as it is said: The stone rejected by the builders bas become the chief comerstone [Psalms 118:22], and as it is said: Who are you great mountain ... and he shall produce the headstone [Zechariah 4:7]. ${ }^{85}$ Thus they interpreted the meaning of "he threw upon Moses" -"that he wanted to throw." ${ }^{66}$ His saying: "How large is the camp of Israel? Three parsangs" - that is to say, how many belong to this nation that occupies an area of three parsangs? I will bring upon them a great king whom I will transfer and transport from his place, one whose army and camp are greater than the camp of Israel, and with his help we will defeat Israel and destroy them. The saying: "[He uprooted a mountain that was three parsangs] and placed it on his head" - he $[\mathrm{Og}]$ accepted him [the powerful king] as a sovereign and submitted himself and his kingdom to him to pay him corvée, as is the way of every noble who has a stronger enemy. "And God

84 Ibn Tibbon had a slightly different version of this passage, and my translation is in accordance with his version and not with our printed texts.

85 "Stone" and "mountain" represent exceptional human beings.

86 In our versions the baraitha reads: "The stone that $\mathrm{Og}$, the king of Bashan, wanted to throw upon Israel" (BT Berakhot 54a), and in the subsequent citation the same wording is used (54b). In Moses Ibn Tibbon's version, the wording was: "The stone that $\mathrm{Og}$, the king of Bashan, threw upon Moses," and in the subsequent citation: "The stone that $\mathrm{Og}$, the king of Bashan, wanted to throw upon Moses," leading him to comment upon the story in the manner he does. 
brought upon him locusts, which bore into the mountain, and it fell upon his head." That is to say, in the city to which the king and his great army gathered in support of $\mathrm{Og}$, God brought about a quarrel between them. As to the saying: "God brought upon him"-a thing that comes to fulfill God's will, or to change and annul what is against the will of God, whether it is something volitional or natural or accidental, is [considered to be] sent by God, the Master of great deeds. They used the word qamza, which means locust, to hint at the swiftness of its coming, hopping and skipping. In the manner that a person can carry a mountain of three parsangs, it is possible that there be a locust that bore into the place [in the mountain] where his head was. ${ }^{87}$ Moreover, this is many more times the measure of the base of his foot to his ankle, even though this measure was 30 cubits. ${ }^{88}$ Maybe this is the measure [from the ground] up to the place which he stood on his chariot in the wooden tower from which he was accustomed to make war, which then does not contradict the verse: bis beight was nine cubits [Deuteronomy 3:11], where it is specified, the cubit of a man. Perhaps the term qamza is used equivocally, referring to avarice and stinginess, in that his [Og's] heart was divided on the matter of the expenses he no longer wanted to bear. Or the intent is that a small group of gossipers (qumza rekbilim) stirred up a quarrel between them, or a fierce controversy. Their saying: "it bore into" - it destroyed the union and love that was between them . . . ${ }^{89}$

The mythic tale that the Sages tell in regard to the war between the Israelite and $\mathrm{Og}$ is interpreted by Ibn Tibbon in terms of wars in the feudal world, with which he was familiar-nobles pledge fealty to kings in order to help them against their enemies in exchange for forced labor, constant quarrels between allies, siege towers to breach fortresses, etc. The stone Og threw is treated by Ibn Tibbon as an actual stone that commemorated Og's defeat, as evidenced by the baraitha that speaks of one praising God when seeing it. The mountain Og uprooted, on the other hand, is a metaphor referring to a powerful king to whom he turned and pledged fealty in exchange for help in his war against Israel. All the fantastic details of the story are explained accordingly. What

87 Hence it is absurd to understand the story literally.

88 According to the continuation of the story, Moses stood ten cubits, and he took an ax that was ten cubits and jumped up ten cubits, striking $\mathrm{Og}$ in his ankle and killing him. This means that Og's height up to his ankle was thirty cubits. Yet for him to carry a mountain of three parsangs, the height would have had to be much greater.

89 The Writings of $R$. Moshe Ibn Tibbon, 191-192. 
appears at first glance as a mythic story is transformed by Ibn Tibbon into a historical account, with the situation prevalent in his own period providing him with the key to understanding this rabbinic tale. ${ }^{90}$

Another exceptionally strange tale Moses Ibn Tibbon explains in a very down to earth manner is the one found in BT Baba Batra 58a, which reads as follows:

R. Bana'ah used to mark out caves [where there were dead bodies]. When he came to the cave of Abraham, he found Eliezer, the servant of Abraham, standing at the entrance. He said to him: What is Abraham doing? He replied: He is sleeping in the arms of Sarah, and she is looking fondly at his head. He said: Go and tell him that Bana' ah is standing at the entrance. Said [Abraham] to him: Let him enter; it is well known that there is no passion in this world. So he went in, surveyed the cave, and came out again. When he came to the cave of Adam, a voice came forth from heaven saying: You have beholden the likeness of my likeness, my likeness itself you may not behold. But, he said, I want to mark out the cave. The measurement of the inner one is the same as that of the outer one [came the answer]. ... R. Bana'ah said: I discerned his two heels and they were like two orbs of the sun. Compared with Sarah, all other people are like a monkey to a human being, and compared with Adam Eve was like a monkey to a human being, and compared with the Shechinah Adam was like a monkey to a human being. ${ }^{91}$

Again drawing from the social reality with which he was acquainted, Moses explains this story as follows: ${ }^{92} \mathrm{R}$. Bana'ah was an artist in the business of decorating crypts for the dead. He once found himself in a house belonging to a person named Abraham, which contained a vault possessing exceptional ancient works of art, and he was interested in a

90 A similar approach based on feudal reality characterizes Moses Ibn Tibbon's explanation of the Talmudic statement in Gittin 57a regarding the three hundred towns belonging to King Yannai; see The Writings of R. Moshe Ibn Tibbon, 193-194. In his Sefer Taninim, he explains the strange tale in BT Baba Batra 74b of the male and female leviathans, the former castrated by God and the latter killed by God and preserved for the righteous in the future, as referring to past and future events occurring to the peoples living to the North and to the South of the Mediterranean Sea; see ibid., 233-237.

91 As translated by Isidore Epstein for the Soncino edition of the Talmud.

92 In this case too, Moses Ibn Tibbon's version of the story is slightly different from the version in our printed editions. 
description of them. He asked Eliezer, the servant in charge, about the vault, who answered that the entrance contained a depiction of the patriarch Abraham lying on the arms of Sarah as she looks down upon his head. R. Bana'ah had a professional interest in seeing this fresco with his own eyes so that he could retain a picture of it in his mind in order to duplicate it. He sent the servant to ask his master for permission to enter, which he was given. He saw that their pose was an immodest one, leading him to criticize the depiction, particularly insofar as it was created in a period known for its modesty. Nevertheless, as was only natural, he wanted to see more of the artwork, and he reached a room where there was a beautiful depiction of Adam. He is told that he may not see the picture, which no one can reproduce due to its great beauty, and even this picture does not do justice to the beauty of Adam when he was alive. In this manner Moses Ibn Tibbon continues to interpret the story, concluding with a discussion of the possible motivations of the ancients who made these beautiful yet immodest representations-either as a memorial or perhaps even to arouse sexual desire. ${ }^{93}$ In short, an incredible story depicting the viewing of our biblical ancestors as still alive and dwelling in some cave is transformed into a tale of the artist who discovers an ancient treasure grove, not unlike such vaults that Moses had heard about in his own time. He is aware, however, that for all its ingenuity, his explanation is not entirely satisfactory. It contains nothing ennobling or thought provoking that would explain why the story was included in the Talmud. For this reason he adds: "If he [the story teller] spoke by way of wisdom, the enlightened one should attempt to find its meaning. "94 That is to say, perhaps the story is in fact a parable concealing philosophic truths, though Moses Ibn Tibbon himself does not make any attempt at such an explanation. For him it is sufficient to show that this story can be understood almost literally once one discerns what it is really describing. ${ }^{95}$

93 The Writings of $R$. Moshe Ibn Tibbon, 198-201.

94 Ibid., 200. See below, chapter 5, 144-145.

95 Compare his explanation of the story of Abba Saul, who entered the thigh bone of Og (BT Niddah 24b), which he treats as part of a giant ancient statue; see The Writings of R. Moshe Ibn Tibbon, 197-198. 


\section{Some Additional Matters in Moses Ibn Tibbon's Writings}

The social situation with which Moses Ibn Tibbon was familiar in his own time also plays a role in his explanation of some of the commandments. The release of inadvertent killers from the cities of refuge with the death of the High Priest, for example, is likened to the amnesty granted at the time of the death of a king - a practice that Moses views as an ancient one, at times with even murderers being pardoned and released. ${ }^{96}$ His explanation of the reason why a person who sells his house in a walled city has only a year in which to redeem it is the need to insure that only those with means would own houses there due to the high general expenses to keep up the fortifications of the city and prepare it for siege, when it can serve also as a place of refuge for the surrounding population. A person who sells for reasons of poverty and can no longer help defray these expenses will not be able to redeem his house within a year, and it would be best if it passes permanently into the possession of a wealthy person, while a rich person who sells for whatever reason might decide to redeem it and is given this opportunity. For a similar reason, Ibn Tibbon maintains that the people living in the city should not be renters but only owners, since one who rents feels he has less of a stake in contributing funds to the defenses of the city. ${ }^{97}$

In addition to the social reasons Moses adduces for some of the commandments, he also sees naturalistic reasons as playing a prominent role in many of them. In his view, the strict laws pertaining to leprosy are due to its being a highly contagious disease. The different forms of impurity identified in the Torah in fact greatly contaminate the air and the surrounding objects, hence the stringent commandments pertaining to them. ${ }^{98}$ Ibn Tibbon also ascribes astrological reasons to some of the commandments. ${ }^{99}$

On occasion, Moses takes the opportunity to criticize certain practices in his own time. For example, he attacks many of his fellow

96 Ibid., 181.

97 Ibid., 172-173.

98 Ibid., 147-148.

99 Ibid., 138. 
physicians for not engaging in preventive medicine, but being more concerned with maximizing their fame and fees, at times even prolonging the patient's illness to increase them. Many judges are seen by him as favoring the rich and even helping them out with their claims, instead of being impartial. Only the philosophers, the seekers of truth, behave in a moral manner in his view. ${ }^{100}$

Even though Moses Ibn Tibbon possessed a highly critical rational mind, as evidenced by his interpretation of traditional literature, he, like most of his contemporaries, was far from immune to a fascination with tales of exotic, faraway places. Some of the most popular books of this genre are collections of tales purportedly reporting the travels of Alexander the Great during his conquests, commonly termed the Alexander Romance. The earlier collections were written in Late Antiquity and later collections in the Middle Ages. Moses was acquainted with a Hebrew translation of one of these collections. ${ }^{101}$ Despite the strangeness of many of the places and people described, he saw no reason to question the historicity of these tales. Furthermore, some of these tales provided him with an insight for interpreting a number of the early stories in the Torah.

After dealing with the location of the Garden of Eden and giving its geographic coordinates-which he locates in the area of Mount Kilimanjaro, or Lunes Montes in Latin (and in Hebrew, Har ha-Yarea $)^{102}$-Moses discusses the climatological traits of this region and its effects on the inhabitants. According to his view, the garden occupies a huge area straddling both sides of the equator, and is

100 Ibid., 150.

101 The version known to Moses Ibn Tibbon was translated from the Arabic, though the original was probably in Latin. Some maintain that the Hebrew translator was his father Samuel. This version was published by Israel Halevi, "Sefer Toldot Alexander," Kobez al Jad 2 (1886): 1-53. In his introduction on pages v-xvi, Halevi discusses the sources of this composition. This version was republished with notes by Joseph Dan, 'Alilot Alexander Moqedon (Jerusalem: Mossad Bialik, 1969). A different medieval Hebrew version of the Alexander Romance was published with introduction and notes by Israel J. Kazis, The Book of the Gests of Alexander of Macedon (Cambridge, MA: The Medieval Academy of America, 1962).

102 See The Writings of R. Moshe Ibn Tibbon, 237-238; cf. Abraham Ibn Ezra, Commentary on Genesis 2:11. 
watered by the sources of the Nile. It is cut off from the surrounding regions by mountains and desert, possesses an ideal climatetemperate throughout the year-and lush vegetation. No iron is to be found there, so no work implements can be made, and the inhabitants live off the food of the land. The heat of the region weakens the natural bodily heat, which in turn affects the character traits of the inhabitants, making them more lethargic, less courageous, and more humble — not seeking greatness, pleasures, and dominion — as opposed to the traits of those who live in colder climes. In support of this picture, Ibn Tibbon cites the account of Alexander's travels in which he came upon groups of people who live in similar climatic conditions. They ate only what naturally grew from the soil and no meat, wore almost no clothes except for covering their private parts with fig leaves, built no homes and slept in caves, possessed no iron, sought no physical pleasures, and lived in perfect harmony with each other, having no need for judges and police, and were exceptionally healthy, having no need for doctors. ${ }^{103}$ While there is some confusion in Ibn Tibbon's account, as well as in his source, whether this place was in India or Africa ${ }^{104}$ - and thus may be the region of the original Garden of Eden-it is clear that he sees in it the key to understanding much of the biblical story. He also cites from Alexander's account of an adjacent region, ${ }^{105}$ where Alexander beheld strange fantastic plants, of beautiful appearance and possessing a wonderful fragrance, which killed a person who touched them. Upon the trees were extraordinary

103 The Writings of R. Moshe Ibn Tibbon, 238-240; cf. 'Alilot Alexander Moqedon, 89-96.

104 In Moses Ibn Tibbon's Hebrew source, it is fairly clear that the account is of Alexander's travels in India. It speaks of two groups there, the "naked ones" and the Brahmins, with the traits described here belonging to the Brahmins, though the "naked ones" share many of the same traits. Yet the Hebrew source also speaks of this area as containing the Pishon River, which is said to flow into the Nile. Ibn Tibbon appears to favor the African location of this account, and that the traits described here belong to the "naked ones." Yet he speaks also of the Brahmins in the same context, who live in an area not so far away, and who appear to possess the same traits. He also indicates that Alexander exchanged letters with them in Hindi. For more on medieval Hebrew descriptions of the Brahmins, see David Flusser, Sefer Yosifon (Jerusalem: Mossad Bialik, 1981), vol. 2, 216-236.

105 This is the region that separated the land of the "naked ones" and the land of the Brahmins. 
birds that made melodic sounds, and when they flew a burning wind issued forth from them that burned all that was below. ${ }^{106}$ In these birds, Ibn Tibbon sees a possible explanation of the identity of the cherubs that God placed at the entrance to the garden.

For all his indebtedness to Maimonides, Moses Ibn Tibbon is much more concerned with explaining in naturalistic terms the literal level of the story of the Garden of Eden, rather than the esoteric. ${ }^{107} \mathrm{He}$ certainly does not deny the esoteric level of the story-his Commentary on Song of Songs is in large part based on the esoteric meaning of this story and there are also allusions to this level in his discussion in Sefer Taninimbut his tendency is to show that even much of the literal level is true. Moreover, there is an integral relation between the literal level and the esoteric one. The moment Adam no longer heeded the divine command and no longer acted according to his natural traits-those that were possessed by the groups that Alexander encountered-but chose instead to pursue extraneous pleasures, then he could no longer remain in this region, which was unsuited for satisfying his new desires. Nor could he later return to it because of the great dangers involved in the journey. Subsequent biblical history highlights the traits acquired by human beings, and that the lands to which they wandered were more suitable from a climatological perspective for these traits. Living closer to the sea, for example, allowed for the import of goods to satisfy the pursuit of pleasure. The metaphorical Adam, Maimonides' figure of pure intellect who loses his perfection when he turns to concentrating on physical matters, mirrors for Ibn Tibbon the historical Adam. Adam was created with an ideal temperament and lived in a physical environment best suited for it. Yet he is tempted to seek extraneous pleasures, and as a result can no longer live in a natural, perfect harmony with his surroundings or with others.

Many more examples can be adduced from the writings that have survived of Moses Ibn Tibbon's naturalistic and novel interpretations

106 The Writings of R. Moshe Ibn Tibbon, 239-240.

107 For an in-depth study of Maimonides' account, see in particular Sara KleinBraslavy, Maimonides' Interpretation of the Adam Stories in Genesis (Jerusalem: Reuben Mass, 1986) (Heb.). 
of stories in biblical and rabbinic literature, as well as his insights into some of the central theological issues of Judaism. While he has gone down in history for being a prime molder of subsequent Jewish philosophy in wake of his activity as a translator, he certainly deserves to be better appreciated as a major pioneering philosophical exegete as well, one who contributed much to the development of this approach for the understanding of Judaism. 